\title{
Original
}

\section{The Combined Effects of Sodium Fluoride and Pyridoxine Hydrochloride: \\ II. in vivo Studies in Animals*}

フッ化ナトリウムと塩酸ピリドキシン併用の有用性

II. 動物を用いた in vivoにおける検討

\author{
Akira ITOH $^{* *}$, Kumiko TANAKA ${ }^{* *}$, Seishiro FUJII ${ }^{* *}$, \\ Minoru FUKUDA ${ }^{* *}$, Hirohisa ARAKAWA ${ }^{* * *}$ \\ and Yoshikazu IIZUKA ${ }^{* * *}$ \\ 伊藤明 ${ }^{* *}$ 田中久美子 ${ }^{* *}$ 藤井誠史 郎 ${ }^{* *}$ \\ 福田實 ${ }^{* *}$ 荒川浩 久*** 飯塚喜 一***
}

Received October 1, 1991 ; accepted November 29, 1991

概要：我々は，従来のフッ化物よりもさらに優れたう蝕予防効果を有する物翼を検索する目的で，フッ化ナ トリウム $(\mathrm{NaF})$ との併用によりその効果を增強させる作用を有する物質について検討した。その結果，酸 性条件下（pH 4.5）で $\mathrm{NaF}$ と塩酸ピリドキシン $\left(\mathrm{VB}_{6} \cdot \mathrm{HCl}\right)$ とを併用すると，合成ハイドロキシアパタ イト粉末 (synthetic HA) へのフッ素取り込み, 耐酸性, 結晶性が向上し, 牛歯エナメル質へのフッ素取り込 みも向上することを明らかにしだ”。そこで次に、 $\mathrm{NaF}$ と $\mathrm{VB}_{6} \cdot \mathrm{HCl}$ の併用によるう蝕抑制効果をラット実 験う強采において検討した。う蝕原性 Streptococcus sobrinus 6715 株を定着させたラットをう蝕誘発性飼 料 Diet \#2000で63日間飼育した。実験期間中を通じて $\mathrm{NaF}+\mathrm{VB}_{6} \cdot \mathrm{HCl}$ 水溶液, $\mathrm{NaF}$ 水溶液, 生理食塩

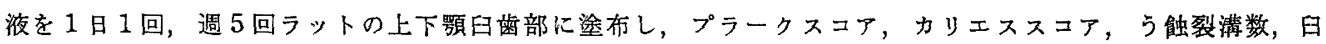
歯へのフッ素の取り込みについて比較検討した。

結果の概要は次の通りである。

1） $\mathrm{NaF}+\mathrm{VB}_{6} \cdot \mathrm{HCl}$ 溶液塗布群および $\mathrm{NaF}$ 溶液塗布群はコントロール群（生理食塩液塗布）に比べプ ラークスコアは有意に低かった。

2) $\mathrm{NaF}+\mathrm{VB}_{6} \cdot \mathrm{HCl}$ 溶液塗布群㧍よび $\mathrm{NaF}$ 溶液塗布群はコントロール群に比べカリエススコアは有意 に低加た。

3) $\mathrm{NaF}+\mathrm{VB}_{6} \cdot \mathrm{HCl}$ 溶液塗布群および $\mathrm{NaF}$ 溶液塗布群はコントロール群に比べう蝕裂溝数は有意に少 なかった。さらに, $\mathrm{NaF}+\mathrm{VB}_{6} . \mathrm{HCl}$ 溶液塗布群は $\mathrm{NaF}$ 溶液塗布群に比べう触裂泘数は有意に少なかった。 4) $\mathrm{NaF}+\mathrm{VB}_{6} \cdot \mathrm{HCl}$ 溶液塗布群および $\mathrm{NaF}$ 溶液塗布群の田歯歯冠部はコントロール群に比べ有意に高

* This paper was presented at the 37 th and 38 th General Session of the Japanese Society for Dental Health held in October, 1988 and 1989.

** Shiseido skin Biology Research Laboratories 凟生堂皮灌科学研究所

*** Department of Dental Health and Public Health, Kanagawa Dental College 神奈川歯科大学口腔衛生学教室 特別揭截 


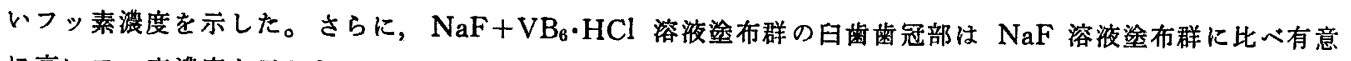
に高いフッ素浱度を示した。

以上の in vivo に扔ける検郡結果より， $\mathrm{NaF}$ と $\mathrm{VB}_{6} \cdot \mathrm{HCl}$ の組み合わせはう強予防に対して非常に有用 であると考えられた。

Koy words: Experimental Caries, Plaque Score, Caries Score, Fissure Caries, Fluoride Uptake

索引用語: 実験う蝕, プラークスコア, カリェススコア, 裂溝う蝕, フッ素取り込み

\section{Introduction}

At present, fluoride has widely contributed to caries prevention by the methods of water fluoridation, fluoride painting, fluoride mouth rinsing, etc ${ }^{2-4}$. Among these methods, fluoride dentifrice is one of the most popular. The fluoride compounds added to dentifrice are mainly sodium fluoride (NaF), sodium monofluorophosphate, or stanous fluoride, and their caries preventing effects have been proven ${ }^{2-4}$. On the other hand, in Europe, organic amine fluoride compounds were developed and have been used in dentifrices. Their excellent effects have been recognized by in vitro, in vivo and clinical experiments ${ }^{5-8}$.

In a previous study, we searched for more effective caries preventive substances combined with $\mathrm{NaF}$ using synthetic hydroxyapatite and bovine enamel. A remarkable enhancing effect of $\mathrm{NaF}$ in combination with $\mathrm{VB}_{6} \cdot \mathrm{HCl}$ at $\mathrm{pH} 4.5$ was recognized ${ }^{1}$. The purpose of this study was to elucidate the in vivo effect of $\mathrm{NaF}$ in combination with $\mathrm{VB}_{6} \cdot \mathrm{HCl}$, using experimental caries in rats, in comaparison with $\mathrm{NaF}$ only.

\section{Materials and Methods}

The experimental design is shown in Fig. 1.

-Experimental animals and feeding-

Sixty 12-day-old Wistar rats, thirty two males and twenty eight femiaes, were obtained from Shizuoka Agr. Corp. for Exp. Animias (Shizuoka, Japan). At 15 days of age, all animals were compulsority weaned by feeding with standard power diet, and after weaning (18 days), they were fed cariogenic Diet\# 2000 (CLEA Japan) until the end of the experiment (81 days). The diet and distilled water were provided ad libitum throughout the experiment. Before weaning, each litter of rats was kept in a plastic cage with its mother, and after weaning, they were separated in stainless cages. The environment was maintained constant at a temperature of $23 \pm 3{ }^{\circ} \mathrm{C}$, a relative humidity of $50 \pm 10 \%$, and $12: 12$ hour light-dark cycle. The rats were weighed once a week to check their health.

-Bacteriological methods-

Streptococcus sobrinus strain 6715 (serotype $g$, resistant to streptomycin) was kindly provided by Dr. T. Koga, NIH, Tokyo. Test strains were grown in 21 of BHI broth (Eiken Chemical Co., Ltd) anaerobically at $37^{\circ} \mathrm{C}$ overnight, centrifuged $\left(5000 \mathrm{~g}, 30 \mathrm{~min}, 4^{\circ} \mathrm{C}\right)$ and suspended in $20 \mathrm{~m} l$ sterile saline. This liquid included about $1.0 \times 10^{10}$ cells per $\mathrm{m} l$. The indigeneous oral was suppressed by providing drinking water containing penicillin G potassium ( $4000 \mathrm{U} / \mathrm{ml}$, Banyu Pharmaceutical Co., Ltd) and a diet containing tetracycine hydrochloride $(4 \mathrm{mg} / \mathrm{g}$, Wako Pure Chemical Industries, Ltd) for three days (15-17 day-old). Bacterial inoculations were started at 18 days of age. $0.1 \mathrm{~m} l$ of the bacterial suspension was applied to the rat mouth with a syringe for six days. Colonization tests were performed on MS-agar just before inoculation and after every two weeks.

-Groups-

At 24 days of age, the rats were divided into three groups: (1) $\mathrm{NaF}+\mathrm{VB}_{6} \cdot \mathrm{HCl}(900 \mathrm{ppmof} \mathrm{F}, 0.97 \%$ 


\begin{tabular}{|c|c|c|}
\hline Days old & $15 \quad 17 \quad 18$ & $23 \quad 24 \quad 25$ \\
\hline Feed & $\begin{array}{l}\text { Compulsory } \\
\vdash \text { weaning }\end{array}$ & - Diet $\# 2000 \longrightarrow$ \\
\hline Antibiotics & $\frac{P G}{\stackrel{\&}{T C}}$ & \\
\hline $\begin{array}{l}\text { Infection of } \\
\text { St. sobrinus }\end{array}$ & & \\
\hline $\begin{array}{l}\text { Colonization } \\
\text { test of } \\
\overline{\text { St. sobrinus }}\end{array}$ & 18 & $\begin{array}{c}24 \\
\text { every } 2 \text { weeks }\end{array}$ \\
\hline $\begin{array}{l}\text { Application } \\
\text { of F/control } \\
\text { solution }\end{array}$ & & $\begin{array}{l}25-81 \\
\text { once a day, } \\
5 \text { days a week }\end{array}$ \\
\hline
\end{tabular}

Fig. 1 Experimental design

$\left.\mathrm{VB}_{6} \cdot \mathrm{HCl}, \mathrm{pH} 4.5\right)$ group, (2) $\mathrm{NaF}(900 \mathrm{ppm}$ of $\mathrm{F}$, $\mathrm{pH}$ 4.5) group, (3)control (saline) group.

-Application of fluoride-

At 25 days of age, rats in the three groups were given 3 minutes of topical application of each fluoride solution or saline once a day, five days a week for eight weeks. The test solutions were applied to the maxillary and mandibular molar teeth with a small cotton swab under anaesthesiag).

- Scoring of dental caries-

Plaque accumulation on the surface of molar teeth was evaluated by the method of Saito et al. ${ }^{10}$ (Table 1). Caries extent in molar teeth was evaluated according to the method of Takei et al ${ }^{11)}$, with some modifications. 22 Specific occlusal fissures were examined under the optical microscope with the aid of a explor and scored according to Table 2, and total scores were regarded as caries score. The number of caries fissures (> grade 1) were compared among the 3 groups.

-Determination of fluoride-

After the caries scoring, all of the molar teeth were extracted and their roots were cut off. The crowns were pooled and ground into power. Fluoride in the crowns was collected by the microdiffusion technique $^{12)}$ and measured with a fluoride ion electrode (ORION 96-09).

\section{Results}

- Growth of animals-

The body weight in each group during the experimental peroid, as shown in Fig. 2, increased satisfactorily, and no significant differences were recogndzed among the 3 groups. No symptom of any disease and no change in diet intake was recongized throughout the experimental period.

-Plaque accumulation-

The plaque score in each group is shown in Table 3 and Fig. 3. In the two fluoride groups, plaque accumulation was significantly $(p<0.01)$ prevented compared with the control group. However, no signifcant difference was seen between the $\mathrm{NaF}$ and $\mathrm{NaF}+\mathrm{VB}_{6} \cdot \mathrm{HCl}$ group. 
Table 3 Effects of $\mathrm{NaF}+\mathrm{VB}_{6} \cdot \mathrm{HCl}$ on plaque accumulation and caries in rats (Mean $\pm \mathrm{SD}$ )

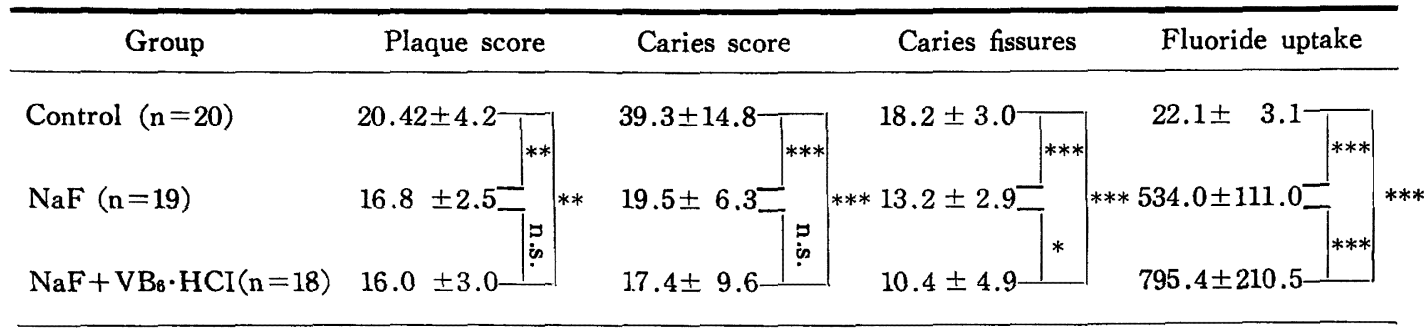

n.s. : not significant *: p $<0.05 * *: \mathrm{p}<0.01 * * *: \mathrm{p}<0.001$

Body weight(g)

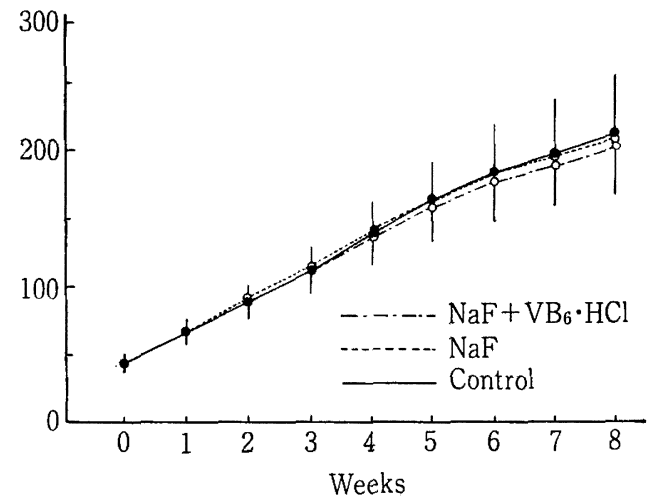

Fig. 2 Changes of body weight in rats

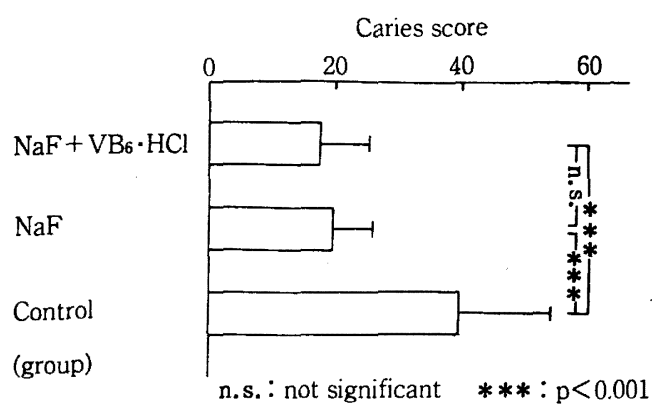

Fig. 4 Caries scores in each group

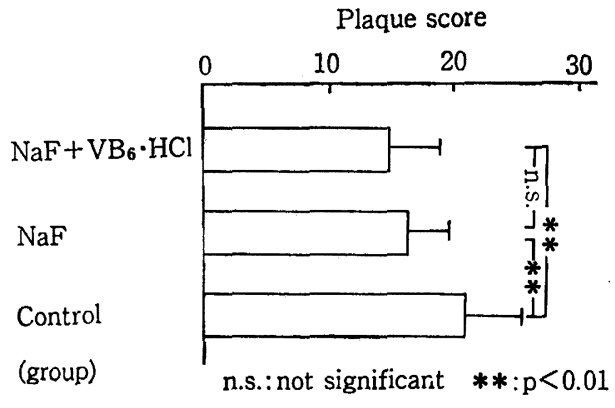

Fig. 3 Plaque scores in each group

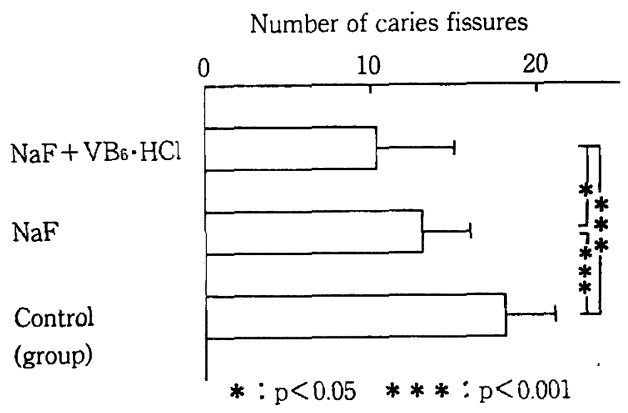

Fig. 5 The number of caries fissures in each group

-Caries incidence and extent-

The caries score in each group is shown in Table 3 and Fig. 4. The caries scores of the two fluoride groups were significantly $(p<0.001)$ lower than that of the control group. However, there was no significant difference between the $\mathrm{NaF}$ and $\mathrm{NaF}+\mathrm{VB}_{6} \cdot \mathrm{HCl}$ group. The number of caries fissures in each group is shown in Table 3 and Fig. 5. As shown in Table 3 and Fig. 5, the caries fissures of the two fluoride groups were significantly $(p<0.001)$ fewer than in the control group. Moreover, the number of caries fissures of the $\mathrm{NaF}+\mathrm{VB}_{6} \cdot \mathrm{HCl}$ group was significantly $(p<0.05)$ fewer than in the $\mathrm{NaF}$ group.

-Fluoride uptake in molar teeth-

Fluoride concentration in the molar crowns of each group is shown in Table 3 and Fig. 6. Fluoride concentration in the teeth of $\mathrm{NaF}$ group was twelve times or more that of the control group. Fluoride 
concentration in the teeth of the $\mathrm{NaF}+\mathrm{VB}_{6} \cdot \mathrm{HCl}$ group was significantly $(p<0.05)$ higher than in the $\mathrm{NaF}$ painting group.

\section{Discussion}

The cariogenic conditions of the rats in this study were (1)being fed cariogenic Diet \# 2000 , (2)compulsory weaning early in the experimental period, and (3) supression of indigeneous oral flora and inoculation with St. sobrinus. Fluoride concentration in the experimental

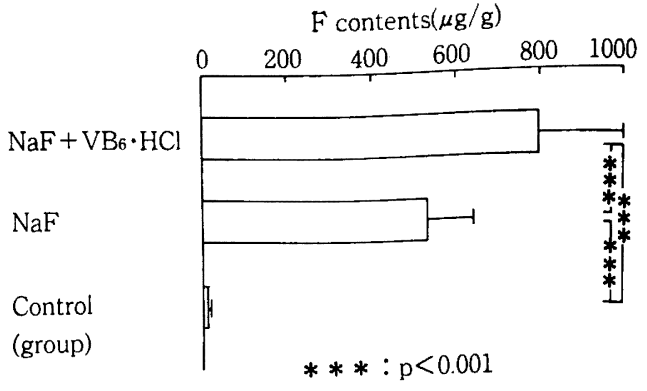

Fig. 6 Fluoride contents in rat's molars in each group

solution was $900 \mathrm{ppm}$, similar to the concentration usually used in dentifrices.

-Plaque accumulation-

Dental plaque formed by oral microorganisms is an important factor of caries induction. Plaqueforming streptococci, for example, streptococcus mutans or streptococcus sobrinus, synthesize the insoluble glucan from sucrose and form dental plaque ${ }^{13,14)}$. At the same time, they produce organic acids by anaerobic glycolysis of sucrose, dissolve the enamel surface, and induce the caries ${ }^{13,14}$.

The prevention of the plaque accumulation by application of fluorides is mainly assumed to be due to the ability of fluorides to inhibit the activity of enzymes in microorganisms ${ }^{15)}$. The fluoride concentration which inhibits the activity of microorganism was about $30 \mathrm{ppm}$ in vitro ${ }^{18)}$.

It has been reported that glucose metabolism of Streptococcus salivarius was supressed by $2 \mathrm{ppm}$ fluoride ${ }^{17}$. In the present study, the plaque accumulation in the fluoride groups was signifiacntly prevented compared with the control group (Fig. 3). Although in vitro effects are not always seen in in vivo cases, in the present study the enzyme activity was inhibited by 3 minutes topical application of $900 \mathrm{ppm}$ fluoride for 56 days, and the formation of plaque was prevented.

- Caries incidence and extent-

In the present study, caries scores in the two fluoride groups were significantly lower than in the control group (Fig. 4). But there was no significant difference between the $\mathrm{NaF}$ group and the $\mathrm{NaF}$ $+\mathrm{VB}_{6} \cdot \mathrm{HCl}$ group. It has been assumed that the mechanism of caries prevention by application of fluoride is the production of fluorapatite (FA) on the enamel surface followed by an enhanced acid resistance of the enamel ${ }^{14,16)}$. However, once the caries extends to the dentin or pulp, fluoride does not prevent caries. Therefore, it is thought that fluoride is prevents caries incidence rather than caries progress. In this study, we detected pulp caries not only in the control group but also in the $\mathrm{NaF}$ and $\mathrm{NaF}+\mathrm{VB}_{6} \cdot \mathrm{HCl}$ groups. This fact seemed to be one reason why there was no difference in caries score between the $\mathrm{NaF}$ group and the $\mathrm{NaF}+\mathrm{VB}_{6} \cdot \mathrm{HCl}$ group. Next, we looked at the prevention of caries incidence, and compared the number of caries fissures. Caries fissures in the $\mathrm{NaF}+\mathrm{VB}_{6} \cdot \mathrm{HCl}$ group were significantly fewer than in the $\mathrm{NaF}$ group. these results, we concluded that the combination of $\mathrm{NaF}$ and $\mathrm{VB}_{6} \cdot \mathrm{HCl}$ was more available for prevention of caries incidence than the separate use of $\mathrm{NaF}$.

-Fluoride uptake in molar teeth-

As mentioned above, the increment of fluoride concentration in teeth by topical application is based on the production of the acid resistance FA in enamel surface. In the present study, after topical application of fluoride for 56 days, fluoride uptake in molar teeth was significantly increased. Fluoride uptake in teeth of the $\mathrm{NaF}+\mathrm{VB}_{6} \cdot \mathrm{HCl}$ group was higher than in the $\mathrm{NaF}$ group. In our previous study, which investigated the fluoride uptake in synthetic $\mathrm{HA}$ and bovine enamel, fluoride uptake of the $\mathrm{NaF}+\mathrm{VB}_{6} \cdot \mathrm{HCl}$ 
treated group was significantly higher than in the $\mathrm{NaF}$ treated group ${ }^{1)}$. We considered that the combination of $\mathrm{NaF}$ and $\mathrm{VB}_{6} \cdot \mathrm{HCl}$ caused the higher fluoride uptake and $\mathrm{FA}$ formation. In this study, we believe that this effect was amplifyed by the repeated application of fluoride to the enamel surface.

\section{Conclusion}

The combined effects of $\mathrm{NaF}$ and $\mathrm{VB}_{6} \cdot \mathrm{HCl}$ on the prevention of casies in rats were studied. Results were as follows :

1) Plaque scores of the $\mathrm{NaF}$ and $\mathrm{NaF}+\mathrm{VB}_{6} \cdot \mathrm{HCl}$ group were lower than in the control group. No significant difference was seen between the $\mathrm{NaF}$ and the $\mathrm{NaF}+\mathrm{VB}_{6} \cdot \mathrm{HCl}$ group.

2) The caries scores of the $\mathrm{NaF}$ and $\mathrm{NaF}+\mathrm{VB}_{6} \cdot \mathrm{HCl}$ groups were lower than in the control group. No significant difference was seen between the $\mathrm{NaF}$ and $\mathrm{NaF}+\mathrm{VB}_{6} \cdot \mathrm{HCl}$ group.

3) Caries fissures in the $\mathrm{NaF}$ and $\mathrm{NaF}+\mathrm{VB}_{6} \cdot \mathrm{HCl}$ groups were significantly fewer than in the control group. Caries fissures in the $\mathrm{NaF}+\mathrm{VB}_{6} \cdot \mathrm{HCl}$ group were also significantly fewer than in the $\mathrm{NaF}$ group.

4) Fluoride uptake in molar teeth was significantly increased by topical application of fluoride. Fluoride uptake in the $\mathrm{NaF}+\mathrm{VB}_{6} \cdot \mathrm{HCl}$ group was significantly higher than in the $\mathrm{NaF}$ group.

The combination of $\mathrm{NaF}$ and $\mathrm{VB}_{6} \cdot \mathrm{HCl}$ appears to be very useful for caries prevention.

\section{References}

1) Tanaka, K., Itoh, A. et al: The combined effects of sodium fluoride and Pyridoxine Hydrochloride: I. In vivo studies, J. Dent. Hlth., 42 ; 7-17, 1992.

2) The Board of Fluoride Reseach, Japanese Society for Dental Health: Guidebook on the topical fluoride apprication (in Japanese), Tokyo, Oral Health Society, pp. 96, 1986.

3) Iizuka, Y., Kaneko, Y. and Takaesu, Y.: Mini-textbook for Dental Health (in Japanese), Tokyo, Gakken shoin, pp. 113, 1983.

4) Caldwell, R. C. and Stallard, R. E. : A textbook of preventing dentistry, W. B. Saunders company, Philadelpia, pp. 1731977.

5) Barbakow, F., Sener, B. et al: Fluoride retention by human enamel after in vitro application of nicomethanol hydrofluoride, J. Dent. Child., 54 ; 9-14, 1987.

6) Schmid, R., Barbakow, F. et al: Amine fluoride and monofluorophosphate, II. Pooled results of 56 independent rat caries tests, J. Dent. Child., 51 ; 104-106, 1984.

7) Shimid, R., Barbakow, F. et al: Amine fluoride and monofluorophosphate, III. Ratcaries inhibition by topical application after using amine fluoride or monofluorophosphate and sodium fluoride dentifrices, J. Dent. Child., $51 ; 107-115,1984$.

8) Shimid, R., Barbakow, F. et al: Amine fluoride and monofluorophosphate, I. Histo- rical review of fluoride dentifries, J. Dent. Child., 51 ; 99-103, 1984.

9) Kani, M., Kani, T. et al: Effect of topical application of ammonium fluoride on the experimental caries in rats (in Japanese), J. Dent. Hlth., 37 ; 63-71, 1987.

10) Saito, K.: The inhibitory effects of Dextranase produced by Chaetomium gracile on the development of dental plaque and caries occurrence in rats (in Japanese), J. Dent. Hlth., 32 ; 71-90, 1982.

11) Takei, M., Suzuki, T. et al: Method of observation for the lesion of experimental dental caries in rats (in Japanese), Jap. J. Oral Biol., 8 ; 130-136, 1967.

12) Tomita, F., Bessho, Y. et al: Significance of fluoride content values in blood serum determined by various analytical methods (in Japanese), J. Dent. Hlth., 35 ; 66-76, 1985.

13) Gibbons, R, J. and Nygaard, M. : Synthesis of insoluble dextran and its significance in the formation of gelatinous deposits by plaque-forming streptococci, Arch. Oral. Biol, $13 ; 1249-1262,1968$.

14) Suga, S. (ed.): Teeth-Science and Its Sorrounding-, Tokyo, Kyoritushuppan, 1981.

15) Kashket, S., Rodrigues, V. M. et al : Inhibition of glucose utilization in oral streptococci by low concentration of fluoride, Caries Res., 11 ; 301-307, 1977.

16) Newbrun, E. (ed.): FLUORIDES AND DENTAL CARIES -Contemporary Con- 
cepts for Practitioners and Students-, Springfield, Charles C Thomas, 1972.

17) Futakami, K., Saito, K. et al: Effects of dextranase, monofluorophosphate, and their combination on the reduction of dental caries and plaque in rats (in Japanese), J. Dent. Hlth., 29 ; 65-71, 1979. 